\title{
PEPTIDES DERIVED FROM A MALARIA PARASITE SURFACE ANTIGEN * EFFECT OF ADJUVANTS AND NUMBER OF IMMUNIZATIONS ON THE TOTAL ANTIBODY RESPONSE IN MICE
}

\author{
R. RAMASAMY AND C. WICKREMARATNE \\ Malaria Laboratory, Division of Life Sciences, Institute of Fundamental Studies, \\ Hantana Road, Kandy.
}

\begin{abstract}
Peptides corresponding to known B cell epitopes in a $45 \mathrm{kDa}$ merozoite surface glycoprotein of the human malaria parasite Plasmodium falciparum were conjugated via 6-maleimido caproic acyl N-succinimide ester 10 bovine serum albumin. The conjugates were used to immunize $\mathrm{Balb} / \mathrm{c}$ mice in saline and with the following adjuvants: Freunds adjuvant, the muramyl dipeptide derivatives murametide and murabutide, and aluminium hydroxide. Three injections of antigen were given intra-muscularly at $21 \mathrm{~d}$ intervals and sera obtained after each injection. Antibody levels against peptides were measured by ELISA. Freunds adjuvant produced the highest titre of antibodies (up to $10^{-5}$ after three injections). Antibody levels obtained with alum absorbed antigen reached titres of $10^{-3}-10^{-4}$ while antigen administered in salire alone yielded titres of $10^{-3}$. The soluble MDP derivatives did not produce higher antibody levels than antigen administered in saline. The results suggest that three injections of peptide-carrier conjugates in alum or saline may be an acceptable procedure for raising sufficiently high titre anti-peptide antibodies in animals and man.
\end{abstract}

Key words: Adjuvant, Immunization, Malaria, Merozoite surface antigen, Plasnodium falciparum, Vaccine.

\section{INTRODUCTION}

Antibodies produced against peptides are used in biological research for a variety of purposes e.g. as probes for determining protein structure, in immunodiagnosis, in identifying protein corresponding to open reading frames in nucleic acid sequences etc. Since anti-peptide antibodies are able to react specifically with the corresponding native protein in many instances, ${ }^{1-3}$ immunization with chemically synthesized peptides is also being developed as a method of vaccinating against infectious diseases. ${ }^{2-4}$ Peptides are often poorly immunogenic and need to be conjugated to carrier proteins or otherwise suitably modified in order to elicit antibodies. ${ }^{4}$ An adjuvant is also regarded as being needed to augment the immune response to peptide-carrier conjugates. ${ }^{5}$ The combination of an emulsion of mineral oil and killed mycobacteria known as Freunds complete adjuvant (FCA) is one of the most potent adjuvants known for stimulating cellular immunity and antibody production. However, it is toxic and produces lesions at the site of injection and is therefore considered to be unsuitable for human use and is not preferred for use with animals. The active component for adjuvant action in mycobacteria has been characterized as $\mathrm{N}$-acetylmuramyl-L-alanyl-D-isoglutamine or muramyl dipeptide (MDP). ${ }^{6}$ MDP 
possesses pyrogenic activity. However, from screening a large number of MDP derivatives, two compounds, murametide ( $\mathrm{N}$-acetylmuramyl-L-Ala-D-Gln- $\mathrm{OCH}_{3}$ ) MUM and murabutide (N-acetylmuramyl-L-Ala-D-Gln-n-butyl ester) MBU that lack pyrogenic activity, and therefore are candidate adjuvants for human use, were identified. $^{5}$

Aluminium salts (alum) have been widely used in traditional human and veterinary vaccines as adjuvants. ${ }^{7}$ Alum has also been used with a recombinant surface protein to induce immunity in man against hepatitis $B{ }^{8}$ Peptide-based vaccines from protein antigens of human malaria parasites are reported to induce partial protection in man when used with alum as an adjuvant. ${ }^{9,10}$ In these studies with malaria peptides, the antibody levels developed were reported to be modest (titres of 1/20-1/400) and cell-mediated responses relatively poor. Conditions for the development of optimal immune responses to peptide antigens therefore require further investigation. A 45 $\mathrm{kDa}$ surface membrane glycoprotein on merozoites of the human malaria parasite Plasmodium falcipanım ${ }^{11,12}$ is one of the candidate molecules for developing a malaria vaccine, since antibodies against defined epitopes of the antigen inhibit parasite growth and reinvasion in cultures. ${ }^{13,14}$ We have used two peptides derived from the sequence of this antigen in the FC 27 strain of $P$. falcipanum ${ }^{12}$ to investigate the effects of FCA, alum, MUM and MBU and the number of immunizations on antibody production in mice.

\section{METHODS AND MATERIALS}

\section{Peptides}

The sequences of synthetic peptides derived from the malaria parasite surface glycoprotein, ${ }^{11,12}$ in the single letter code for amino acids, were as follows :

$\begin{array}{lll}\text { Peptide } & \text { Residues } & \text { Sequence } \\ \text { P102 } & 122-138 & \text { TAADTPTATESISPSPPC } \\ \text { P103 } & 207-226 & \text { RNNHPQNTSDSQKECTDGNK }\end{array}$

P102 contains a B cell epitope that is present in one of the allelic forms of the $45 \mathrm{kDa}$ antigen and is the target of an inhibitory monoclonal antibody. ${ }^{14}$ P103 is a relatively hydrophillic sequence that on independent structural analysis was shown to contain predicted B and T cell epitopes. Both P102 and P103 are recognized by antibodies present in up to $60 \%$ of the sera of persons living in a $P$. falcipanum endemic area of Sri Lanka (submitted for publication).

A cysteine was incorporated into the C-terminus of P102 for coupling, while P103 contained a naturally occurring cysteine in position 221 . Peptides were synthesized by 
standard t-Boc solid phase chemistry as modified for multiple synthesis. ${ }^{15}$ They were analysed and purified by reverse phase high performance liquid chromatography (HPLC) using a C18 column and a Shimadzu 8A liquid chromatograph (Shimadzu, Tokyo). A gradient of acetonitrile containing $0.1 \%$ trilluoroacetic acid was used for elution. The eluted peptides were lyophilised and stored desiccated at $-20^{\circ} \mathrm{C}$ until use. The HPLC profiles of peptide 102 and peptide 103 and the fraction used in the experiments are shown in Figure 1 and Figure 2 respectively. The amino acid composition, determined after complete hydrolysis of the peptides, using the Waters Picotag system (Waters, Bedford, MA), was consistent with the expected sequence of the peptides.

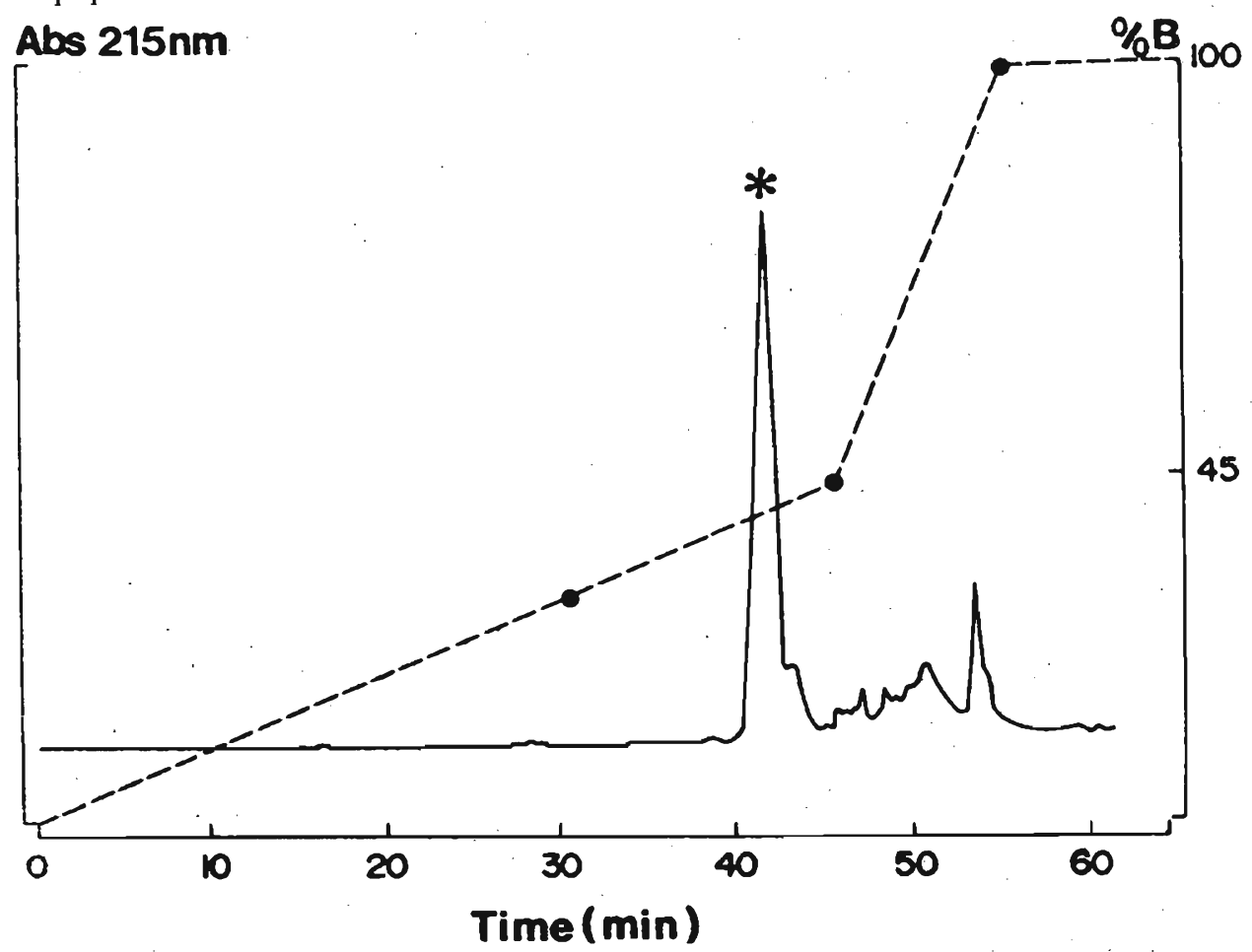

Figure 1: IIPLC separation of peptide 102. The gradient of acetonitrile (solvent B) employed is indicated by the broken line. Absorbtion was measured at $215 \mathrm{~nm}$ and is given in arbitary units. Elution was performed at $10 \mathrm{ml} \mathrm{min}^{-1}$. The peak containing peptide is indicated by an asterisk.

\section{Preparation of peptide carrier conjugates}

The peptides were covalently linked to bovine serum albumin using 6-maleimido caproic acyl N-succinimide ester (MCS) essentially as described previously. ${ }^{16}$ Briefly, to a solution of $5 \mathrm{mg}$ bovine serum albumin (BSA) in $0.45 \mathrm{ml}$ of $0.01 \mathrm{M}$ sodium phosphate buffer, $\mathrm{pH} 7.5,0.05 \mathrm{ml}$ of $50 \mathrm{mM}$ MCS in dry dimethylformamide was added 


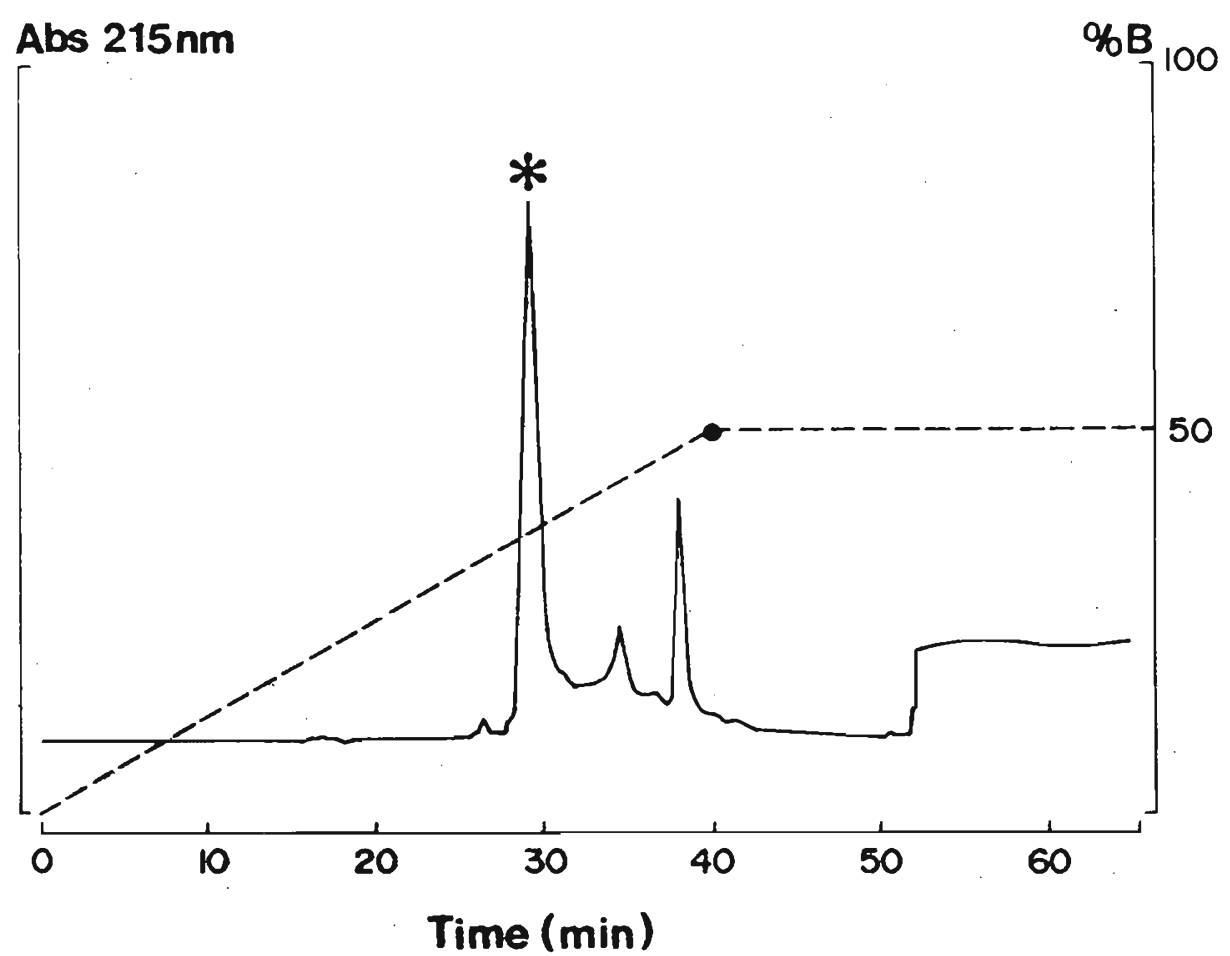

Figure 2: IIPLC separation of peptide 103. The gradient of acetonitrile (solvent $B$ ) is indicated by the broken line. Absorbtion was measured at $215 \mathrm{~nm}$ and is given in arbitary units. Elution was performed at $10 \mathrm{ml} \mathrm{min}^{-1}$. The peak containing peptide is indicaled by an asterisk.

and the mixture gently shaken for $30 \mathrm{~min}$ at $26^{\circ} \mathrm{C} .0 .05 \mathrm{ml}$ of the MCS solution was again added and the incubation continued for a further $30 \mathrm{~min}$. The maleimidated protein was then dialysed against $0.1 \mathrm{M}$ sodium phosphate $\mathrm{pH} 6.5$. $5 \mathrm{mg}$ of peptide was dissolved in $0.5 \mathrm{ml}$ of $0.1 \mathrm{M}$ sodium phosphate, $\mathrm{pH} 6.5,1 \mathrm{mM}$ EDTA and added to $0.5 \mathrm{ml}$ of the maleimidated serum albumin. The mixture was equilibrated with nitrogen, sealed in a nitrogen atmosphere and incubated for $18 \mathrm{~h}$ at $26^{\circ} \mathrm{C}$. The peptide-carrier conjugate was then dialysed against several changes of $0.01 \mathrm{M}$ phosphate buffered saline $\mathrm{pH} 7.2$ (PBS).

The conjugation ratio determined by comparison of the $M_{r}$ of the peptide-carrier conjugate with maleimidated carrier by sodium dodecyl sulphate-polyacrylamide gel electrophoresis (SDS-PAGE).

\section{Production of antisera}

Groups of 4 nine month old Balb/c mice were injected, for primary and boosting immunizations, with peptide - carrier conjugate equivalent to $50 \mu \mathrm{g}$ of peptide per 
mouse intra-muscularly at two sites. Female mice were used for immunization with P102 and PBS control and male mice for immunization with P103. (a) For FCA immunization, the first injection was given in FCA followed by incomplete Freunds adjuvant for the boosting injections. (b) For immunization with the two MDP derivatives, $100 \mu \mathrm{g}$ of MBU and MUM in PBS were mixed with the conjugates for the primary and boosting injections. (c) For immunization with alum, aluminium hydroxide precipitate was washed in PBS and the conjugate absorbed onto it for injection. Both primary and boosting injections contained alum. (d) For immunization without adjuvant, mice were injected with the conjugate in PBS.

Boosting injections were given on day 21 and day 42 and the mice tail bled for sera $10 \mathrm{~d}$ after each injection. After the third injection the mice were sacrificed and bled out. Pre-immune sera were also collected before commencing the immunizations.

\section{Quantitation of antibodies}

Anti-peptide antibody levels were determined by enzyme linked immunosorbent assay (ELISA) using peptides as antigens. Costar 96 well microtitre plates (Biorad, Richmond, CA) were coated with $0.05 \mathrm{ml}$ of a $0.01 \mathrm{mg} \mathrm{m}^{-1}$ solution of peptide in PBS overnight at $37^{\circ} \mathrm{C}$. Unreacted absorption sites in the wells were blocked with a $5 \% \mathrm{wt}$ vol $^{-1}$ solution of non-fat milk powder (Blotto) for $2 \mathrm{~h}$ at $26^{\circ} \mathrm{C}$. The wells were washed and then incubated with $0.05 \mathrm{ml}$ of tenfold serial dilutions of individual mouse sera for $2 \mathrm{~h}$ at $26^{\circ} \mathrm{C}$. After washing four time in PBS, the wells were treated with $0.05 \mathrm{ml}$ of a 1:2000 dilution of sheep anti-mouse IgG - horse radish peroxidase conjugate with $H$ and L chain specificity (Silenius, Melbourne, Australia) in Blotto for $1 \mathrm{~h}$. This reagent detects all murine immunoglobulin isotypes. The wells were then washed and the colour reaction developed with 2,2' -azino -bis (3-ethyl benz thiazoline - 6- sulphonic acid) and $\mathrm{H}_{2} \mathrm{O}_{2}$ for 30 min. Optical density at $405 \mathrm{~nm}$ was then measured in a Multiskan Plus II ELISA reader (Flow labs, Irvine, Scotland).

\section{RESULTS}

Molecular weight determination by SDS-PAGE analysis demonstrated that 12 mols of P102 and 16 of P103 were present per mol of BSA in the two conjugates (data not shown). The individual mice within a group yielded antisera with similar reactivity and specificity in the ELISA. Hence the mean absorption at $405 \mathrm{~nm}$ obtained with sera within a group are presented below.

Anti-P103 antibodies raised with alum as adjuvant specifically reacted with P103 compared to P102 (Figure 3) and vice versa (data not shown). Similar specificity was observed with antisera produced using the other adjuvants and without adjuvant and 


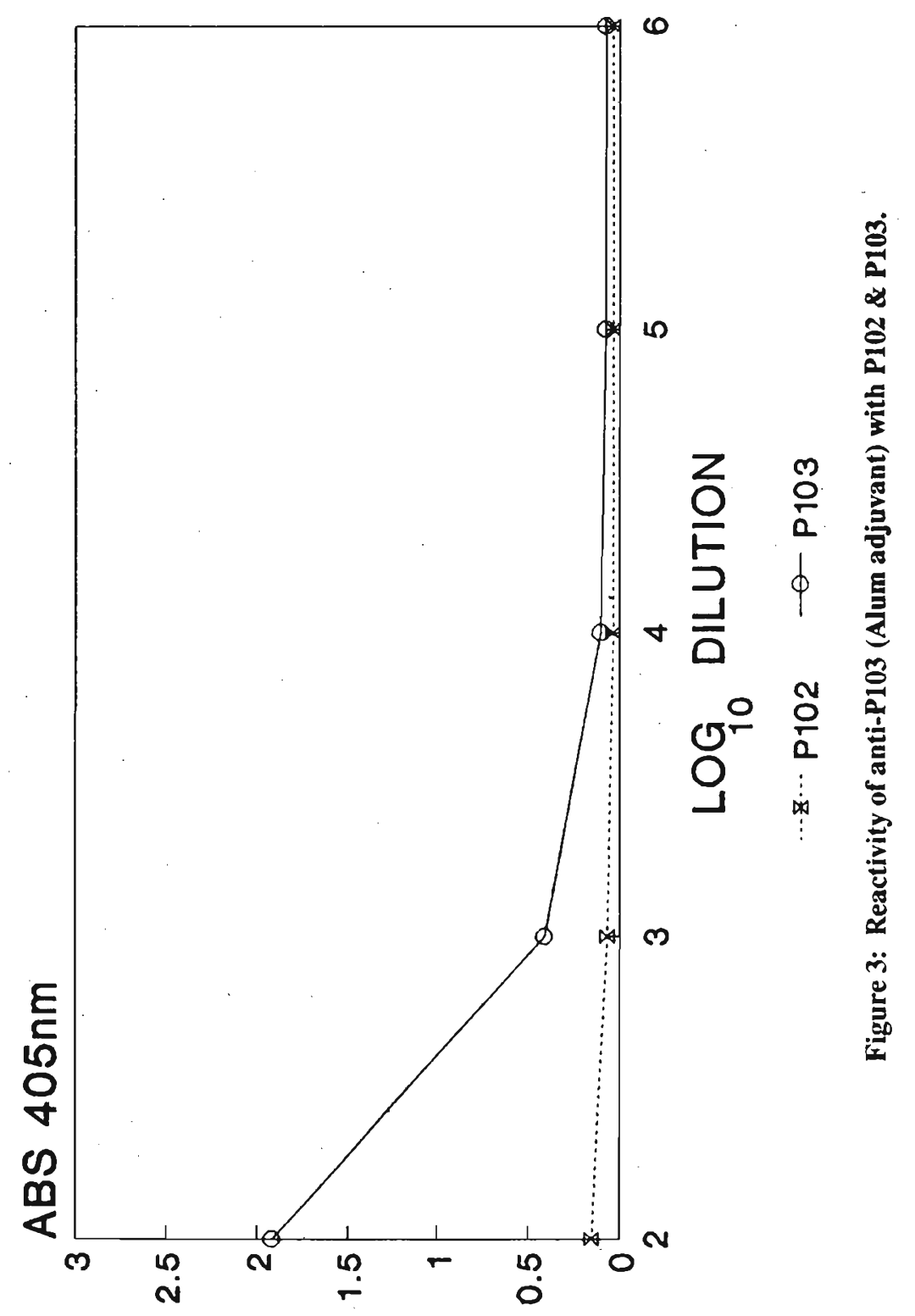




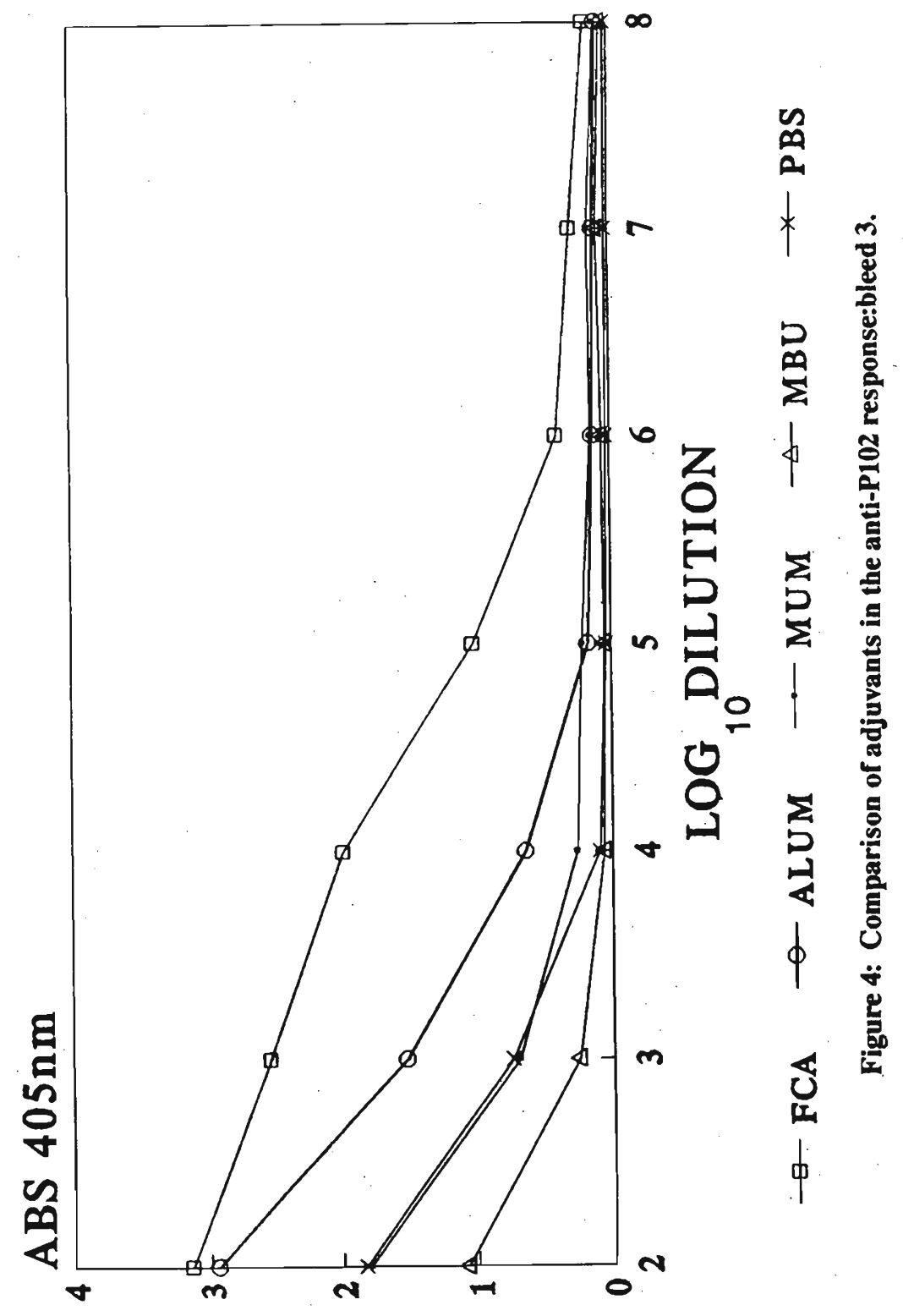




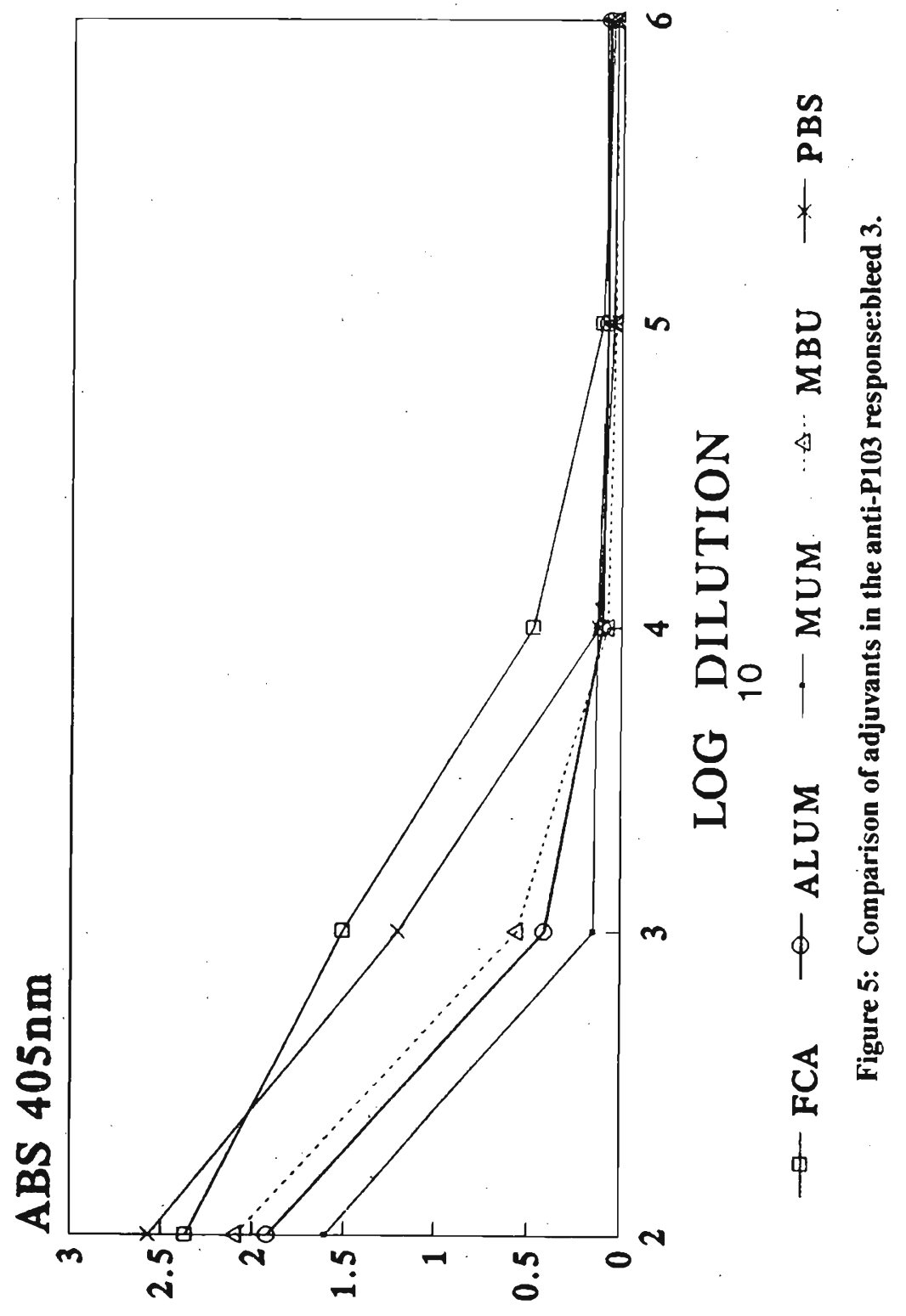


when sera were tested against peptides conjugated to an unrelated carrier protein, kcyhole limpet haemocyanin, (KLH), through glutaraldehyde.

Highest titres of anti-peptide antibodies were obtained with Freunds adjuvant when the sera obtained after three injections with P102-BSA (Figure 4) and P103-BSA (Figure 5), were tested by ELISA. While antibody titres of $10^{-4}-10^{-5}$ were observed with Freunds adjuvant, titres of $10^{-3}-10^{-4}$ were seen when alum was used as an adjuvant and $10^{-3}$ after immunization without adjuvant. MBU and MUM did not significantly increase antibody production when compared to injections given without adjuvant.

Three injections were generally necessary to obtain significant antibody production with P102-BSA and P103-BSA when Freunds adjuvant was not used since the antibody responses after two injections in such cases were weak (Figures $6 \& 7$ ). However, appreciable antibody response was detected with P103 after two injections when mice were immunized with P103-BSA in PBS only (Figure 7). A comparative analysis of the pre-immune sera and sera obtained after each injection of P102-BSA with alum as adjuvant clearly showed that three injections were needed for significant antibody production (Figure 8). Similar results were obtained with the corresponding anti-P103 sera.

\section{DISCUSSION}

The results show that immunization with Freunds complete adjuvant followed by Freunds incomplete adjuvant for subsequent injections gave the best result with peptide-BSA conjugates for anti-peptide antibody production. However, after three injections, the antibody response to injections of antigen without adjuvant and with alum as adjuvant were sufficiently strong to yield antibody titres of $10^{-3}-10^{-4}$. Similar results were obtained with two additional peptides conjugated to BSA (unpublished observations). Thus immunization without adjuvant or with alum as an adjuvant for peptide-carrier conjugates may be sufficient for many purposes and has the advantage that it avoids the use of an adjuvant that is toxic and produces locally severe lesions.

MBU and MUM did not show significant advantage as adjuvants in the present study. This may be because MBU and MUM, as is the case with MDP ${ }^{5}$ are cleared rapidly from blood. Hence delivery in an aqueous medium ${ }^{17}$ may be less effective than when MDP or its derivatives are given as an emulsion with minęral oil and antigen. ${ }^{6}$ The covalent linkage of MBU and MUM to the peptide-carrier conjugate may be an alternative way of enhancing adjuvant action since this has been shown to be effective with MDP. ${ }^{18}$ 


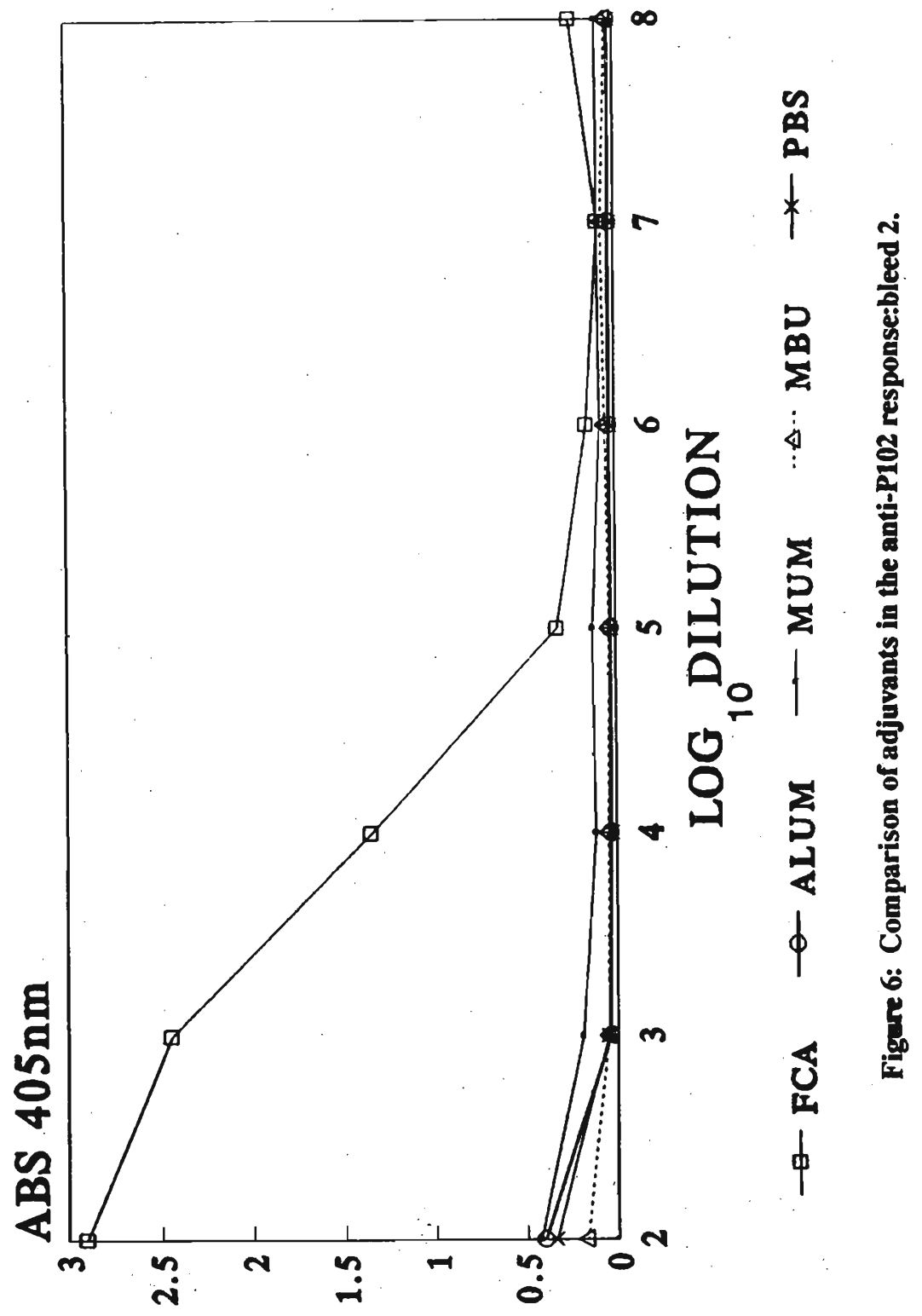




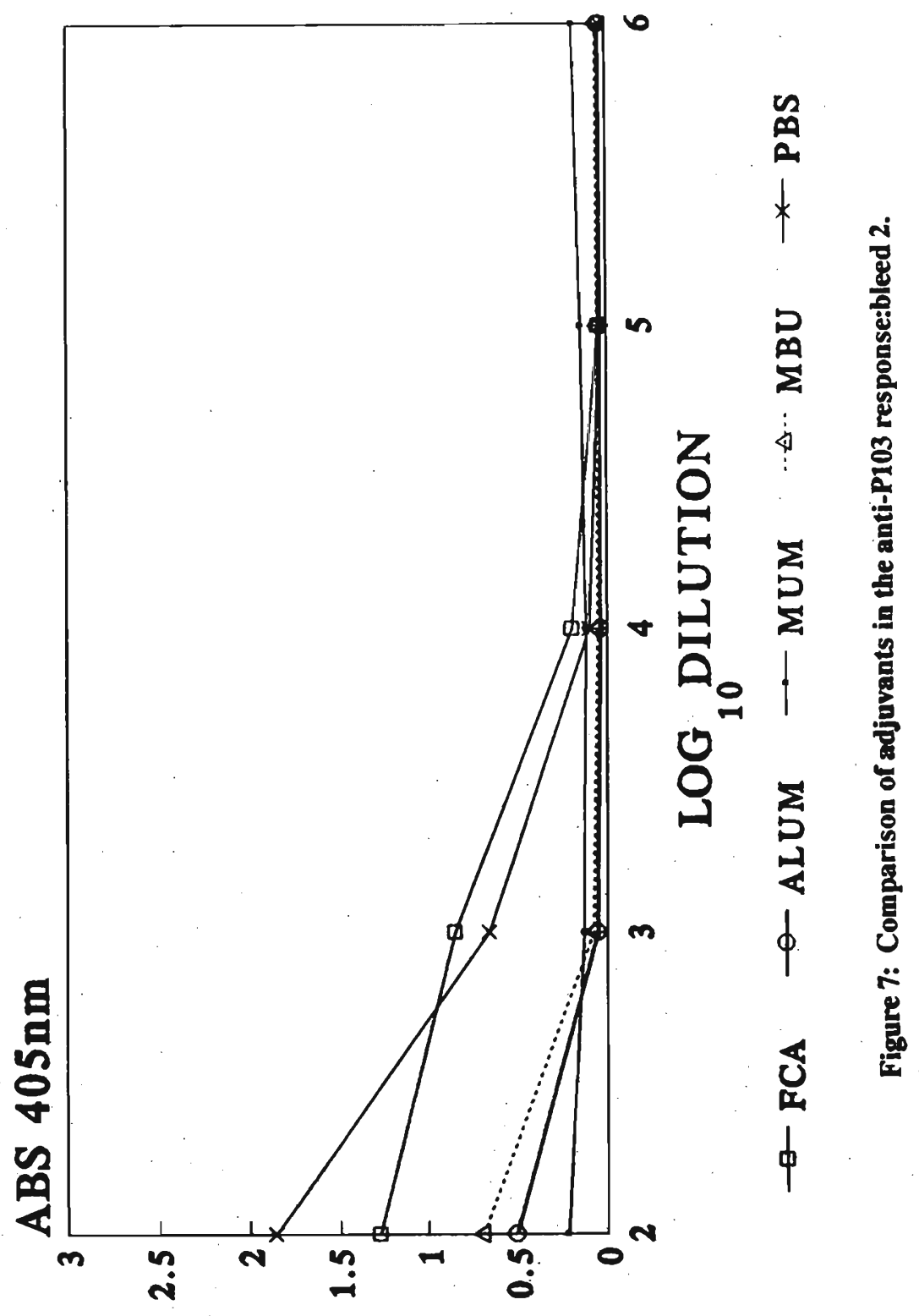




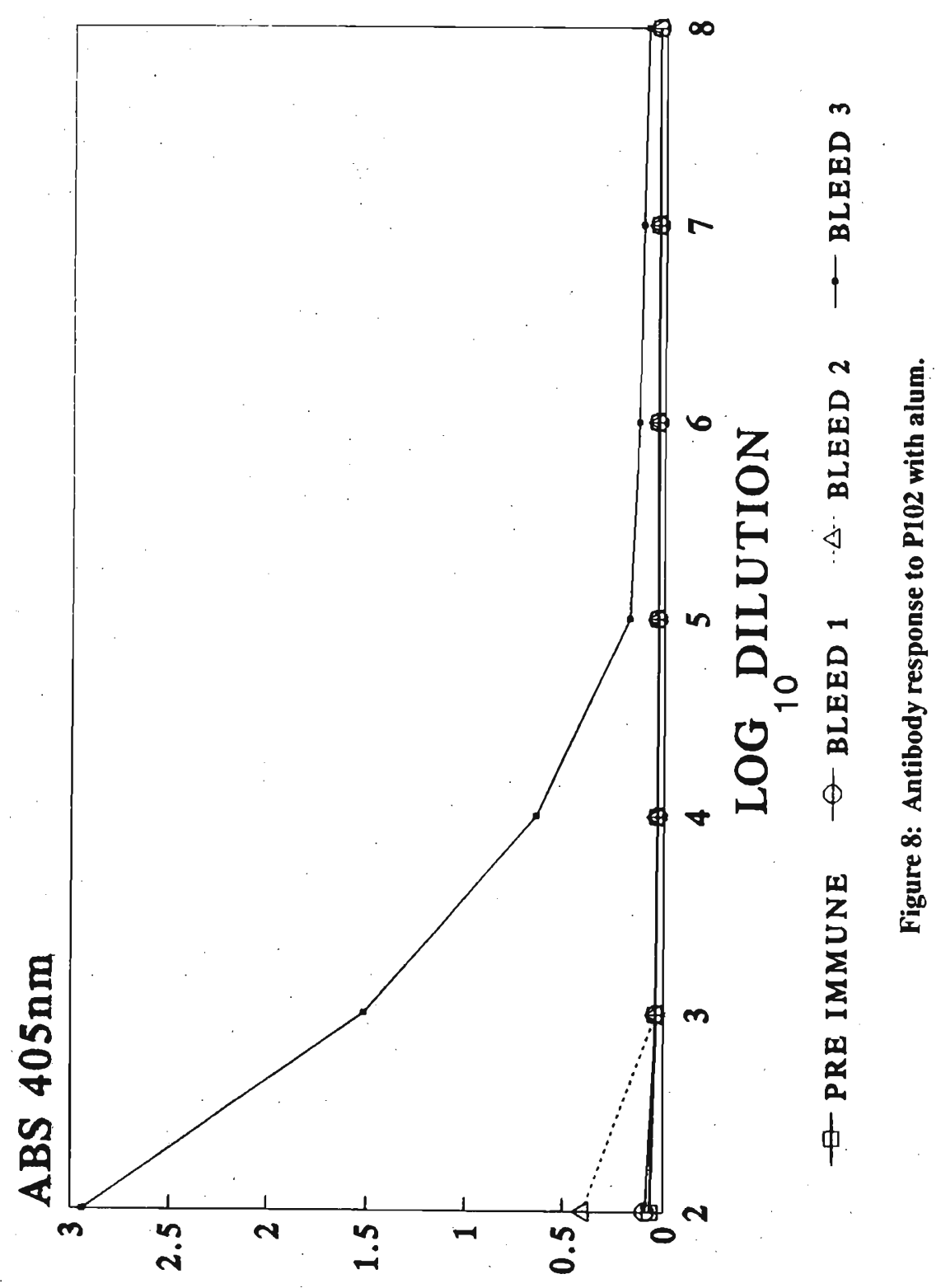


Immunofluorescence studies with acetone/methanol fixed asexual blood stages of P.falcipanim showed that anti-P102 but not anti-P103 sera reacted with the merozoite surface (unpublished observations). This indicates that the peptide sequence and its location within GYMSSA may be important in eliciting antibodies reactive with native GYMSSA.

In general, the antibody responses to P102 and P103 induced by the different immunization schedules were similar except that P103 induced a greater antibody response when injected in PBS than in alum. The reason for this discrepancy is not clear, but it may be related to the presence of a T-cell activating determinarit in $\mathrm{P} 103^{19}$ but not P102. Cellular as well as humoral immunity has been shown to act against asexual blood stage malaria parasites in man. ${ }^{20}$ No attempt was made to measure $\mathrm{T}$ cell responsivenesss in the present investigation. Immunization with alum is generally considered to induce poor $\mathrm{T}$ cell immunity. ${ }^{7}$ However, significant $\mathrm{T}$-cell responsiveness was observed in mice immunized in alum with a herpes simplex virus glycoprotein derived peptide conjugated to ovalbumin. ${ }^{21}$ Different immunoglobulin isotypes that are reported to be selectively induced by different adjuvants, ${ }^{5}$ and which may have different effector functions in immunity, were also not measured in the present investigation. Immunization with peptide vaccines derived from the sporozoite ${ }^{9}$ and asexual blood stage ${ }^{10}$ P. falciparum proteins, in alum as an adjuvant, produced immunofluorescence and ELISA antibody titres of $1 / 20-1 / 400$ in human sera. The poor antibody response to the sporozoite protein was attributed to previous exposure to the tetanus toxoid carrier inhibiting the antibody response, ${ }^{9}$ a process which may be overcome with further antigen injections. ${ }^{22}$ Antibody titres observed in our study are comparable to the serum antibody levels against a $185-200 \mathrm{kDa}$ merozoite surface protein that completely protect owl monkeys against $P$. falciparmm malaria (immunofluorescence titres of $\left.10^{-3}-10^{-4}\right){ }^{23}$ Higher ELISA antibody titres $\left(10^{-5}\right)$ against sporozoite antigens have been produced in mice using alum absorbed liposomes containing lipid $\mathrm{A}$ and peptide-carrier. ${ }^{24}$ The toxic effects of lipid $\mathrm{A}$ and liposomes however need to be further investigated before human use. ${ }^{5}$ Our results show that useful antibody levels against peptides can be produced in mice, and potentially therefore in humans, after three injections of peptide-carrier conjugates in PBS or aluminium hydroxide, an adjuvant commonly used in man and domestic animals.

\section{Acknowledgements}

We thank Dr. R. A. Houghten, Torrey Pines Institute for Molecular Studies, La Jolla for providing facilities for peptide synthesis, R. K. U. de Silva for assistance and Dr. F. Audibert, Institute Pasteur, Paris for gifts of murametide and murabutide. 


\section{References}

1. Anderer F.A. (1963). Preparation and properties of an artificial antigen immunologically related to tobacco mosaic virus. Biochimica Biophysica Acta 71: $245-248$.

2. Arnon R. (1986). Peptides as immunogens: prospects for a synthetic vaccine. Current topics in Microbiology and Immunology 130: 1-12.

3. Lerne R.A. (1982). Tapping the immunological repertoire to produce antibodies of predetermined specificity. Nature 299: 592-596.

4. Ramasamy R. (1991). Synthetic peptides in malaria research. Peptide Research 4: 210-219.

5. Warren H.S., Vogel F.R. \& Chedid L.A. (1986). Current status of immunological adjuvants. Annual Reviews of Biochemistry 4: 369-388.

6. Ellousz F., Adam A., Ciorbarn R. \& Lederer E. (1974). Minimal structural requirements for adjuvant activity of bacterial peptidoglycan derivatives. Biochemical Biophysical Research Communications 59: 1317-1325.

7. Nicklas W. (1992). Aluminium salts. Research in Immunology 143: 489-494.

8. Scolnick E.M., McLean A.A., West D.J., McAleer W.J., Miller W.J. \& Buynak, E.B. (1984). Clinical evaluation in healthy adults of a hepatitis $\mathrm{B}$ vaccine made by recombinant DNA. Joumal of the American'Medical Association 251: 2812-2815.

9. Herrington D.A., Clyde D.F., Losonsky G., Cortesia M., Murphy J.R., Davis J., Bagar S., Felix A.M., Heimer E.P., Gillessen D., Nardin E., Nussensweig R.S., Nussensweig V. \& Levine M.M. (1987). Safety and immunogenicity of a synthetic peptide malaria vaccine against Plasmodium falciparum sporozoites. Nature 328: $257-259$.

10. Pataroyo M.E., Amador R., Clavijo P., Moreno A., Guzman F., Romero P., Tascon R., Franco A., Murillo L.A., Ponton G. \& Trujillo G. (1988). A synthetic vaccine protects humans against challenge with asexual stages of Plasmodium falciparum malaria. Nature 332: 158-161.

11. Ramasamy R. (1987). Studies on glycoproteins in the human malaria parasite Plasmodium falciparum. Identification of a myristilated $45 \mathrm{kDa}$ merozoite membrane glycoprotein. Immunology and Cell Biology 65: 419-424.

12. Smythe J.A., Coppel R.L., Brown G.V., Ramasamy R., Kemp D.J. \& Anders R.F. (1988). Identification of two integral membrane proteins of Plasmodium falcipartm. Proceedings of the National Academy of Sciences, USA 85: 5195-5199. 
13. Ramasamy R. \& Geysen H.M. (1990). Novel cross-reactive epitopes on asexual blood stage antigens of Plasmodium falciparum. Parasite Immunology 12: 457-471.

14. Ramasamy R., Jones G. \& Lord R. (1990). Characterization of an inhibitory monoclonal antibody defined epitope on a malaria vaccine candidate antigen. Immunology Letters 23: 305-310.

15. Houghten R.A. (1985). General method for the rapid solid phase synthesis of large numbers of peptides: specificity of antigen-antibody interaction at the level of individual amino acids. Proceedings of the National Academy of Sciences, USA 82: 5131-5135.

16. Lee A.C.J., Powell J.E., Tregear G.W., Niall H.D. \& Stevens V.C. (1980). A method for preparing $-\mathrm{hCG} \mathrm{COOH}$ peptide carrier conjugates of predictable composition. Molecular Immunology 17: 749-756.

17. Cluugh E.R., Audibert F.M., Barnwell J.W., Schlesinger D.H., Arnon R. \& Chedid L.A. (1985). Biologically active antibodies elicited by a synthetic circumsporozoite peptide of Plasmodium knowlesi administered in saline with a muramyl dipeptide derivative. Infection and Immunity. 48: 839-842.

18. Audibert F., Jolivet M., Chedid L., Arnon R. \& Sela M. (1982). Successful immunization with a totally synthetic diphtheria vaccine. Proceedings of the National Academy of Sciences, USA 79: 5042-5046.

19. Rzepczyck C.M., Ramasamy R., Mutch D.A., Ho P.C.L., Battistutta D., Anderson K.L., Parkinson D., Doran T.J. \& Honeyman M. (1989). Analysis of human T cell response to two Plasmodium falciparum merozoite surface antigens. European Joumal of Immunology 19: 1797-1802.

20. Ramasamy, R. and Ramasamy, M.S. (1989). Progress towards a molecular vaccine against malaria. Indian Joumal of Malariology 26: 127-148.

21. Geerligs H.J., Weijer W.J., Welling G.W. \& Welling-Wester S. (1989). The influence of different adjuvants on the immune response to a synthetic peptide comprising amino acid residues 9-21 of herpes simplex virus type 1 glycoprotein D. Joumal of Immunological Methods 124: 95-102.

22. Etlinger H.M. \& Altenburger W. (1991). Overcoming inhibition of antibody responses to a malaria recombinant vaccinia virus caused by prior exposure to wild type virus. Vaccine 9: 470-472.

23. Siddiqui W.A., Tam L.Q., Kramer K.J., Hui G.S.N., Case S.E., Yamaga K.M., Chang S.P., Chan E.B.T. \& Kan S.C. (1987). Merozoite surface coat precursor protein completely protects Aotuis monkeys against Plasmodium falcipanum malaria. Proceedings of the National Academy of Sciences, USA 84: 3014-3018. 
24. Richards R.L. Hayrc M.D., Hockmeycr W.T. \& Alving C.R. (1988). Liposomes, lipid $A$ and aluminium hydroxide enhance the immune response to a synthetic malaria sporozoite antigen. Infection and Immunity 56: 682-686. 